\title{
INVERTASE AND SUCROSE SYNTHASE ACTIVITIES IN COFFEE PLANTS SPRAYED WITH SUCROSE SOLUTION
}

\author{
José Carlos da Silva ${ }^{1}$; José Donizeti Alves ${ }^{1,3 *}$; Amauri Alves de Alvarenga ${ }^{1,3}$; Marcelo Murad \\ Magalhães ${ }^{1,2}$; Dárlan Einstein do Livramento ${ }^{1,2}$; Daniela Deitos Fries ${ }^{1,4}$ \\ ${ }^{1}$ UFLA - Depto. de Biologia/Setor de Fisiologia Vegetal, C.P. 37 - 37200-000 - Lavras, MG - Brasil. \\ ${ }^{2} C B P \& D$ - Café Fellow. \\ CNPq scholar. \\ ${ }^{4}$ CAPES scholar. \\ *Corresponding author <jdalves@ufla.br>
}

\begin{abstract}
One management practice of which the efficiency has not yet been scientifically tested is spraying coffee plants with diluted sucrose solutions as a source of carbon for the plant. This paper evaluates the effect of foliar spraying with sugar on the endogenous level of carbohydrates and on the activities of invertase and sucrose synthase in coffee (Coffea arabica L.) seedlings with reduced (low) and high (normal) levels of carbon reserve. The concentrations used were 0.5 and $1.0 \%$ sucrose, and water as a control. The use of sucrose at $1.0 \%$ caused an increase in the concentration of total soluble sugars in depauperate plants, as well as increased the activity of the following enzymes: cell wall and vacuole acid invertase, neutral cytosol invertase and sucrose synthase. In plants with high level of carbon reserve, no increments in total soluble sugar levels or in enzymatic activity were observed. Regardless of treatments or plants physiological state, no differences in transpiration or stomatal conductance were observed, demonstrating the stomatal control of transpiration. Photosynthesis was stimulated with the use of 0.5 and $1.0 \%$ sucrose only in depauperate plants. Coffee seedling spraying with sucrose is only efficient for depauperate plants, at the concentration of $1.0 \%$.
\end{abstract}

Key words: Coffea arabica L., sugar, spray, enzymes

\section{ATIVIDADE DE INVERTASES E SACAROSE SINTASE EM PLANTAS DE CAFEEIRO PULVERIZADAS COM SOLUÇÃO DE SACAROSE}

\begin{abstract}
RESUMO: Uma prática cuja eficiência não foi ainda comprovada cientificamente, é a pulverização dos cafeeiros com solução diluída de sacarose, como fonte de carbono para as plantas. Este trabalho visou estudar o efeito da pulverização de açúcar via folha nos teores endógenos de carboidratos e na atividade das enzimas invertases e sacarose sintase em mudas de cafeeiros (Coffea arabica L.) com baixo (baixo) e alto (normal) nível de reservas de carbono. As pulverizações ocorreram nas concentrações de 0,5 e $1 \%$ de sacarose utilizandose água como testemunha. A aplicação de sacarose a 1\% aumentou a concentração de açúcares solúveis totais (AST) em plantas depauperadas, como também aumentou as atividades das enzimas invertase ácida da parede, invertase ácida do vacúolo, invertase neutra do citosol e sacarose sintase. Em plantas com níveis normais de carboidratos não foi observada nenhuma alteração nos teores dos AST, como também nas atividades de tais enzimas. Independentemente dos tratamentos aplicados e do estado fisiológico das plantas, não foram observadas diferenças na transpiração e na condutância estomática, mostrando, desta forma, o controle estomático da transpiração. A fotossíntese foi estimulada a $0,5 \%$ e $1 \%$ em plantas depauperadas, o que não aconteceu com plantas normais. A pulverização de sacarose em mudas de cafeeiros só é eficiente tratando-se de plantas depauperadas na concentração de $1 \%$.

Palavras-chave: Coffea arabica L., açúcar, pulverização, enzimas
\end{abstract}

\section{INTRODUCTION}

Coffee growers adopt certain management practices that, in most cases, lack scientific evidence. These procedures affect productivity and increase production costs, without assuring that the investment will actually provide financial benefits. One such practice is spraying the leaves with a diluted sugar solution as a carbon source for the plants.
Given that the only form of carbon acquisition by plants is photosynthesis, and since this process can easily be affected by adverse edaphic-climatic conditions, many technicians or growers believe that providing exogenous carbon through foliar application of sucrose or molasses might efficiently supply this element to the plant (Mangini et al., 1998; Santinato et al., 1998).

In Brazil, the first research involving sucrose spraying on coffee plants was carried out by Segura- 
Monge (1989) aiming to determine the participation of this sugar in maintaining adequate water levels in the plant. Contrary to published research, under dehydration conditions, plants sprayed with sucrose at concentrations of up to $15 \%$ showed a decrease in total soluble sugar content. In the same study, when water deficiency was incipient (-0.5 $\mathrm{MPa}$ to $-1.0 \mathrm{MPa})$ or severe $(-2.5 \mathrm{MPa})$, sucrose sprays did not produce changes in the plant water status, as compared to the control. Under an intermediate water deficit (-1.5 MPa), a quadratic response curve was observed for the leaf water potential, with the maximum point at a concentration of $10 \%$ sucrose. The improvement in seedling water status was attributed to the physical effect of the sucrose layer on the leaf surface, reducing water loss by transpiration. At rates higher than $10 \%$, the same sugar layer could have promoted leaf tissue dehydration, with the consequent drop in water potential.

From these studies, other experimentes were conducted with the objective of supplying carbon to plants by spraying them with different products, industrialized or not. There are no differences in productivity for the coffee plant when sugar or molasses are applied together with zinc sulfate and boric acid sprays (Mangini et al.,1998). In several treatments no differences were observed between sugar or molasses sprays and the control. Likewise, applying boric acid alone was more efficient to increase productivity of coffee plants, as compared to spraying different salts in the presence of sucrose (Lima et al., 1998). Similar results were obtained by Santinato et al. (1998), who verified that applying sugar to increase the productivity of coffee plants is innocuous.

With the exception of the work by Segura-Monge (1989), who tried to link the effect of applying sucrose to the physiology of the plant under semi-controlled conditions, all other studies had their work carried out under field conditions. All of those experiments had coefficients of variation between 21 and $36 \%$, what makes data interpretation a difficult endeavor.

Even failing to produce evidence of differences between treatments, the authors of these papers concluded that spraying coffee plants with sucrose is beneficial, based on aleatory differences of tendencies and relative increases, disregarding the statistical analyses. On the other hand, Garcia et al. (1999), working with coffee seedlings, observed that the application of several commercial sugar products had very little influence on the vegetative development of the seedlings. They therefore concluded that many products have been introduced and recommended for coffee cropping as foliar applications without any scientific foundation. In a recent review focusing on several aspects of foliar nutrition of coffee plants (Rena \& Fávaro, 2000), clearly indicate that when proper rates of certain nutrients are utilized in the soil and when the crop is conducted in a rational and scientific manner, supplementing with foliar applications of mineral or organic elements does not result in any additional benefits for the development and production of coffee plants.

Currently there is no research work dealing with the influence of the application of sugars on the carbon metabolism in the coffee crop. The objective of this work was to verify the effect of sucrose sprays on coffee seedlings at different levels of foliar carbon reserves, on endogenous carbohydrate contents and on the activity of invertases and sucrose synthase.

\section{MATERIAL AND METHODS}

Plant material consisted of eight month old cultivar RUBI coffee seedlings, line MG 1192. Seedlings were grown in $11 \times 22 \mathrm{~cm}$ plastic bags, containing a substrate formed by hillside soil $(70 \%)$ and bovine manure (30\%), fertilized according to technical recommendations (Guimarães et al., 1998). Seedlings were standardized by size and then removed from the nursery, gradually exposed to 50 and $80 \%$ solar radiation, and finally to full sun to complete the acclimation process. seedlings were then transferred to a growth room set at $27^{\circ} \mathrm{C}$ and approximately $50 \%$ relative humidity, split into two groups. The first group remained in the dark for 72 hours, which is a period long enough to lower the total soluble sugar content in the leaves to $3.8 \mathrm{mg} \mathrm{g}^{-1}$ of dry matter. The other group remained, for the same period, under a 12 hour photoperiod at a photosynthetically active radiation of $400 \mathrm{mmmol} \mathrm{m} \mathrm{m}^{-2} \mathrm{~s}^{-1}$, enough to maintain a dry matter carbohydrate content of $7.2 \mathrm{mg} \mathrm{g}^{-1}$.

At the fourth day, 75 minutes after exposing both groups of plants to a $400 \mathrm{mmol} \mathrm{m} \mathrm{m}^{-2} \mathrm{~s}^{-1}$ radiation, they were sprayed with $20 \mathrm{~mL}$ of sucrose solutions per plant at concentrations of 0.5 and $1 \%$, with distilled water as a control. The experimental design was randomized blocks with three replicates. Treatment means were analyzed by the $\mathrm{t}$ test for $\mathrm{F}$ values that indicated significance $(P<0.05)$.

Samples were collected from expanded leaves for the invertase and total soluble sugar assays, and from young leaves for the sucrose synthase assay, at 40 minute intervals, for four hours after the application of treatments, and then the photosynthetic, transpiration and stomatal conductance activities were evaluated by means of an IRGA gaseous exchange system, model LCA-4, in totally illuminated and expanded leaves. The samples were maintained in a freezer at $-86^{\circ} \mathrm{C}$ until the chemical analyses were carried out.

To extract the sucrose synthase, leaf samples were macerated in liquid nitrogen in the presence of 50 mmol L ${ }^{-1}$ of HEPES buffer - $\mathrm{NaOH}, \mathrm{pH} 7 ; 2 \mathrm{mmol} \mathrm{L}^{-1}$ $\mathrm{MgCl}_{2}, 2 \mathrm{mmol} \mathrm{L}^{-1}$ DDT and $1 \mathrm{mmol} \mathrm{L}{ }^{-1}$ EDTA, at the rate 
of $1 \mathrm{~g}$ tissue per $10 \mathrm{~mL}$ extraction buffer (Déjardin et al., 1997). After centrifugation at 20,000 $\mathrm{g}$ for 10 minutes, the enzyme activity was determined in the supernatant according to Chourey (1981).

For invertase extraction, $50 \mathrm{mmol} \mathrm{L}^{-1}$ of phosphate buffer, $\mathrm{pH} 7.5,1 \mathrm{mmol} \mathrm{L}^{-1} 2$-mercaptoethanol and $5 \mathrm{mmol} \mathrm{L}^{-1} \mathrm{MnSO}_{4}$ were utilized, at the same rate as described above. After centrifugation at 20,000g for $20 \mathrm{~min}-$ utes, the vacuole acid and neutral cytosol invertase activities were quantified in the supernatant, while the cell wall acid invertase was extracted from the precipitate, by using the same phosphate buffer, diluted 40 times. The activities of the corresponding enzymes were determined according to Lowell et al. (1989). All extraction steps were performed at $4^{\circ} \mathrm{C}$.

The total soluble sugars were quantified according to methodology described by Yemm \& Willis (1954), for the vacuole and cytosol invertase enzyme extract.

\section{RESULTS AND DISCUSSION}

The total soluble sugar (TSS) contents in the leaf gradually dropped to $3.8 \mathrm{mg} \mathrm{g}^{-1} \mathrm{MS}$, during the 96 hour period in which the seedlings remained in the dark (Figure 1). Despite of the low carbohydrate contents, resulting from respiration consumption, the seedlings were in good vegetative condition after remaining in the dark. In the same time interval and under a 12 hour photoperiod, another group of plants maintained a mean and constant foliar content of $7.2 \mathrm{mg} \mathrm{g}^{-1} \mathrm{MS}$. In this experiment, to obtain seedlings with low carbohydrate content, the adopted procedure was to expose plants to the dark for $72 \mathrm{~h}$. Seedlings submitted for $72 \mathrm{~h}$ to a consecutive photoperiod of 12 hours were considered as normal.

In general, the TSS contents in the leaves of seedlings considered as normal, up to a period of 4 hours from spraying with water, sucrose at $0.5 \%$, and at $1 \%$, did not differ among themselves (Figure 2). By the end of that period, the contents were at the same levels as those ob-

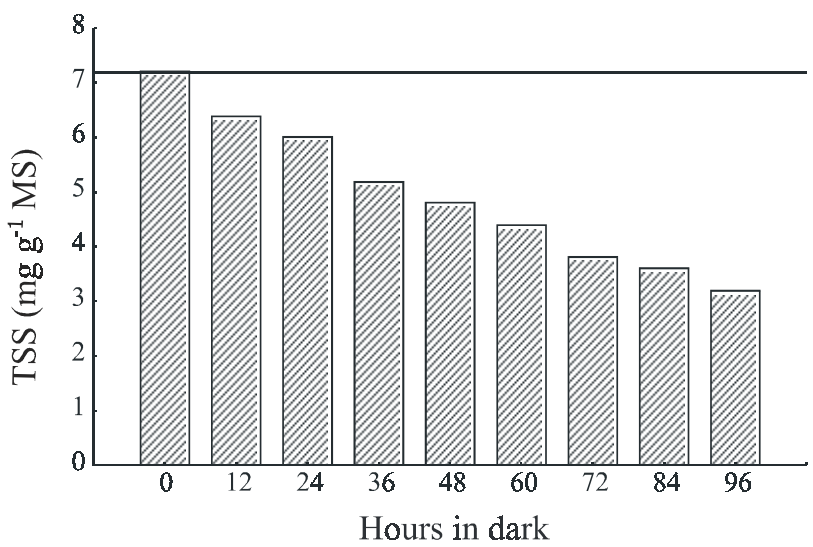

Figure 1 - Total soluble sugar (TSS) contents in coffee seedling leaves during 96 hours of darkness and under a 12 hour photoperiod (continuous line). served before the application of treatments. On the other hand, in seedlings with low carbohydrate content, considered as depauperate, an increase in foliar TSS content was observed $40 \mathrm{~min}$. after spraying with sucrose solutions at $1 \%$. During this time interval, the sprays with $1 \%$ sucrose solution always provided higher TSS contents than the $0.5 \%$ concentration sprays. Treatments with $0.5 \%$ sucrose only produced increases at 160 minutes, which reverted at subsequent times.

Under dehydration conditions, Segura-Monge (1989) observed decreases in TSS content in the leaves of coffee seedlings five days after spraying with $15 \%$ su-
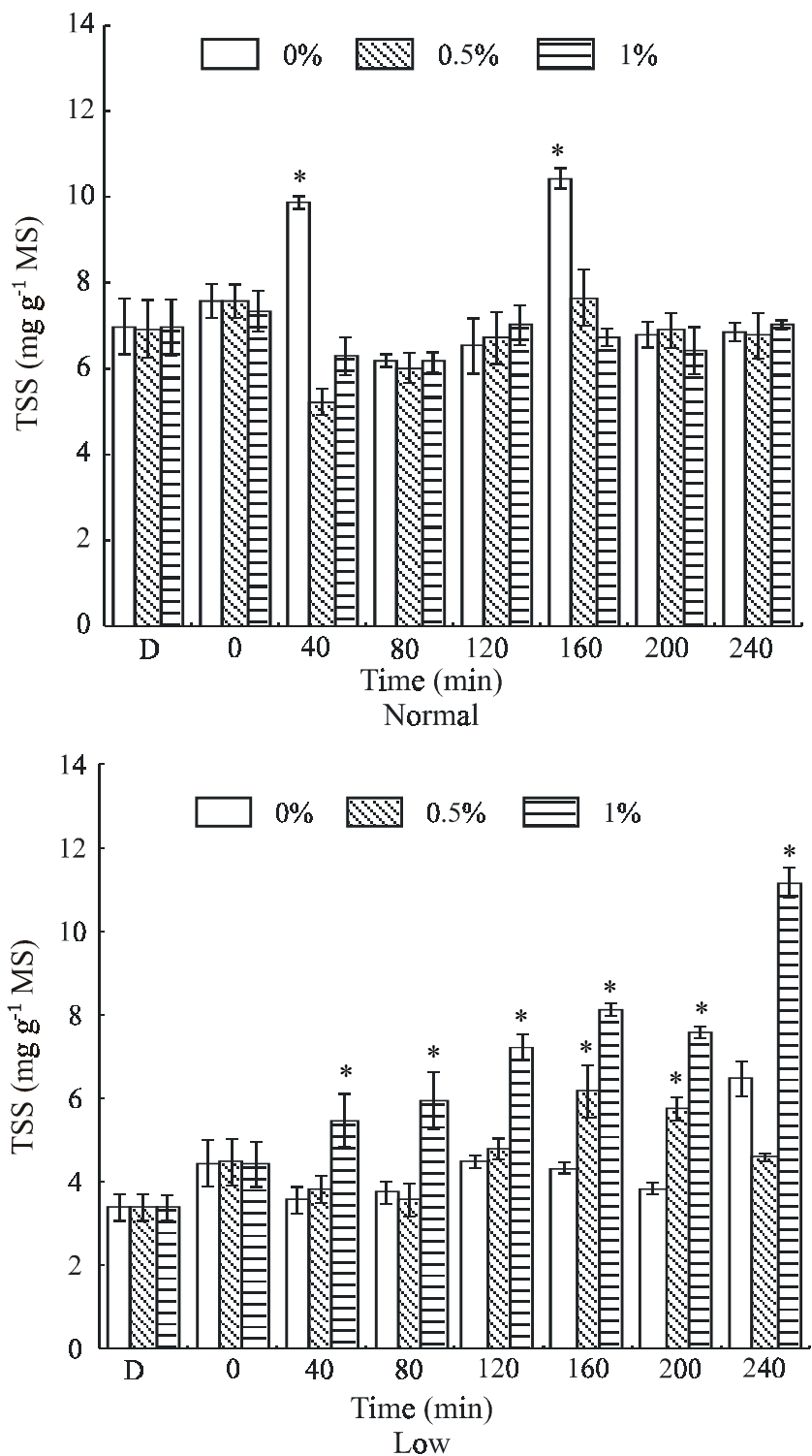

Figure 2 - Total soluble sugar (TSS) contents in coffee seedling leaves under two endogenous carbohydrate concentrations, normal and low, after application of sucrose at concentrations of 0.5 and $1 \%$, and water as a control (bars indicate the $95 \%$ confidence interval of the mean). $\mathrm{D}=$ Dark; $0=75$ min after start of lighted period. * Difference $(P<0.05)$ between sugar application and water. 
crose, attributing this decrease to sugar mobilization to other parts of the plant or to its participation as a respiratory substrate. In this work, the four hour sampling time was considered too short to detect the same effects. However, the application of foliar sucrose in coffee seedlings was only effective in increasing endogenous sugar contents when plants showed low carbohydrate reserves.

In normal plants, where no TSS content alterations were observed with the different sprays, in general no differences were detected in invertase and sucrose synthase activity (Figures 3 and 4). However, in depauperate plants, only when plants were sprayed with $1 \%$ sucrose, a defined pattern could be observed. Greater increases in activity relative to the control were observed, concurrently with the increase in TSS contents, 40 minutes after spraying for cell wall acid and neutral invertases (Figure 3), and vacuole acid invertase and sucrose synthase (Figure 4). The increase in activity of enzymes that degrade sucrose in leaves that received this carbohydrate at $1 \%$ could be associated with the increase in endogenous sugar concentration supplied by the spray. A substantial part of the endogenous sugar was assimilated
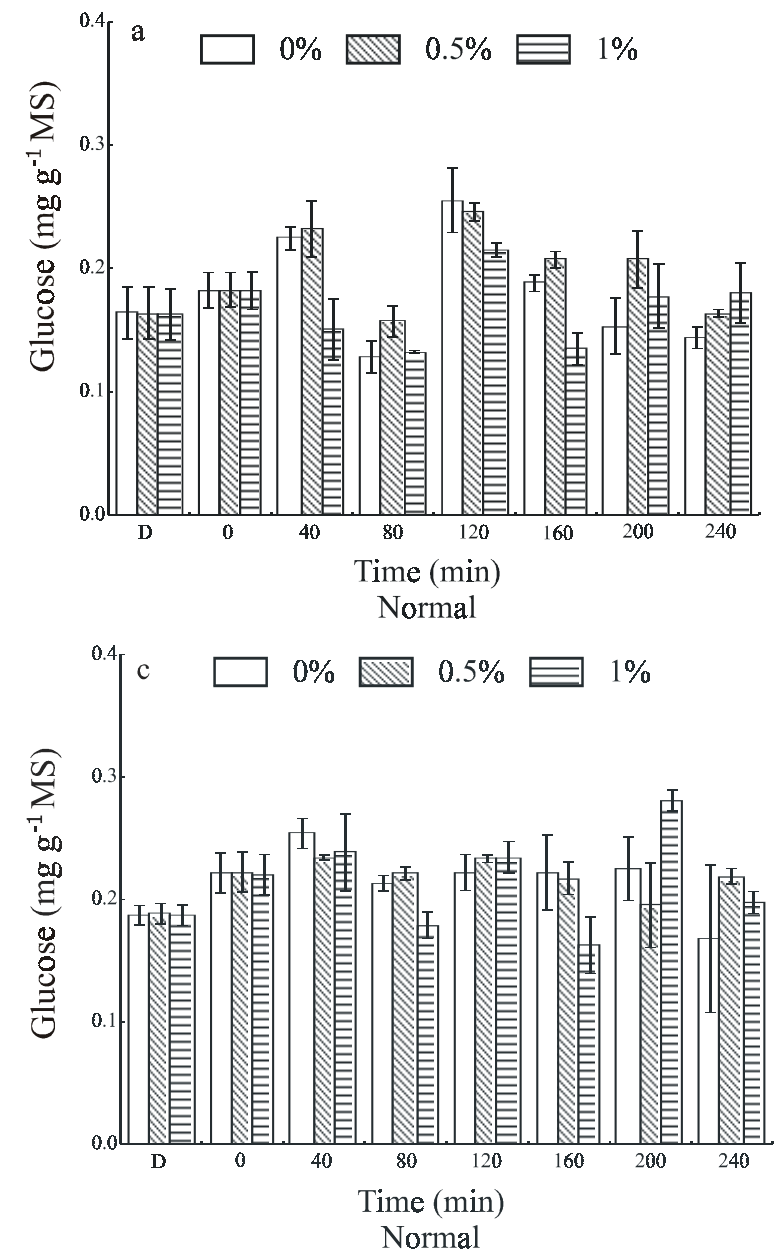

in the leaf itself, since it has been demonstrated for other plant species that in most instances sucrose absorption depends on its cleavage in a reaction catalyzed by invertases or sucrose synthase (Kruger, 1990; Rees, 1984).

The importance of these enzymes in tissues undergoing active growth, in which hexoses are highly demanded as substrates for several metabolic processes such as glycolysis, biosynthesis of starch, triacylglycerides or other molecules that take part in the primary and secondary metabolisms, has been demonstrated (Gayler \& Glasziou, 1972; Isla et al., 1992; Ho, 1988), as well as sucrose synthase for cell expansion and division (Winter \& Huber, 2000). However, the hypothesis that another fraction of this sugar could have been exported to sink tissues, such as roots, for example, must not be rejected.

No differences were observed in plant transpiration or stomatal conductance (Figure 5) by the end of the experiment. Segura-Monge (1989) observed that spraying with a sucrose solution at 5 or $10 \%$ led to higher water potential levels in coffee plants under dehydration conditions, because it formed a layer of sugar on the leaf surface, reducing water loss by transpiration. These results
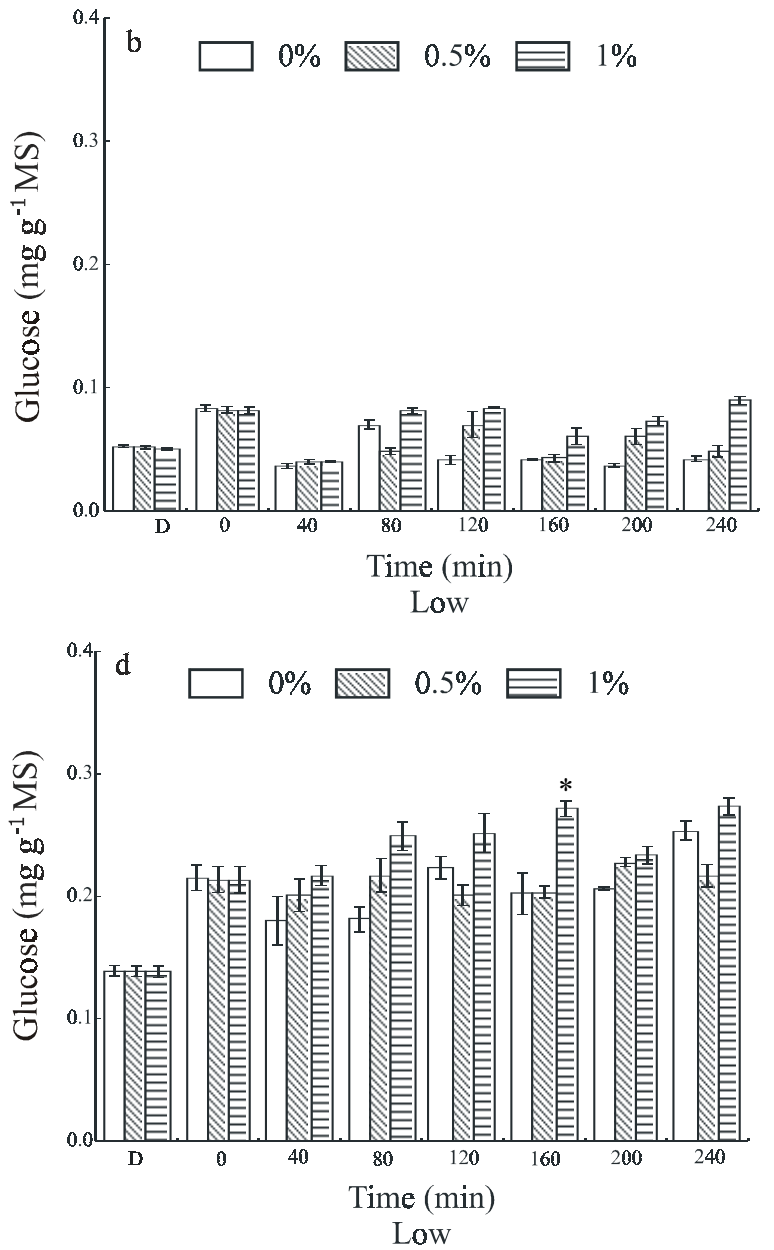

Figure 3 - Activity of cell wall acid invertase ( $a$ and b) and neutral invertase (c and d) in coffee seedling leaves under two endogenous carbohydrate concentrations, normal and low, after application of sucrose at concentrations of 0.5 and $1 \%$ and water as a control, in a 40-minute assay (bars indicate the $95 \%$ confidence interval of the mean). $\mathrm{D}=\mathrm{Dark} ; 0=75$ min after start of lighted period. * Difference $(P<0.05)$ between sugar application and water. 

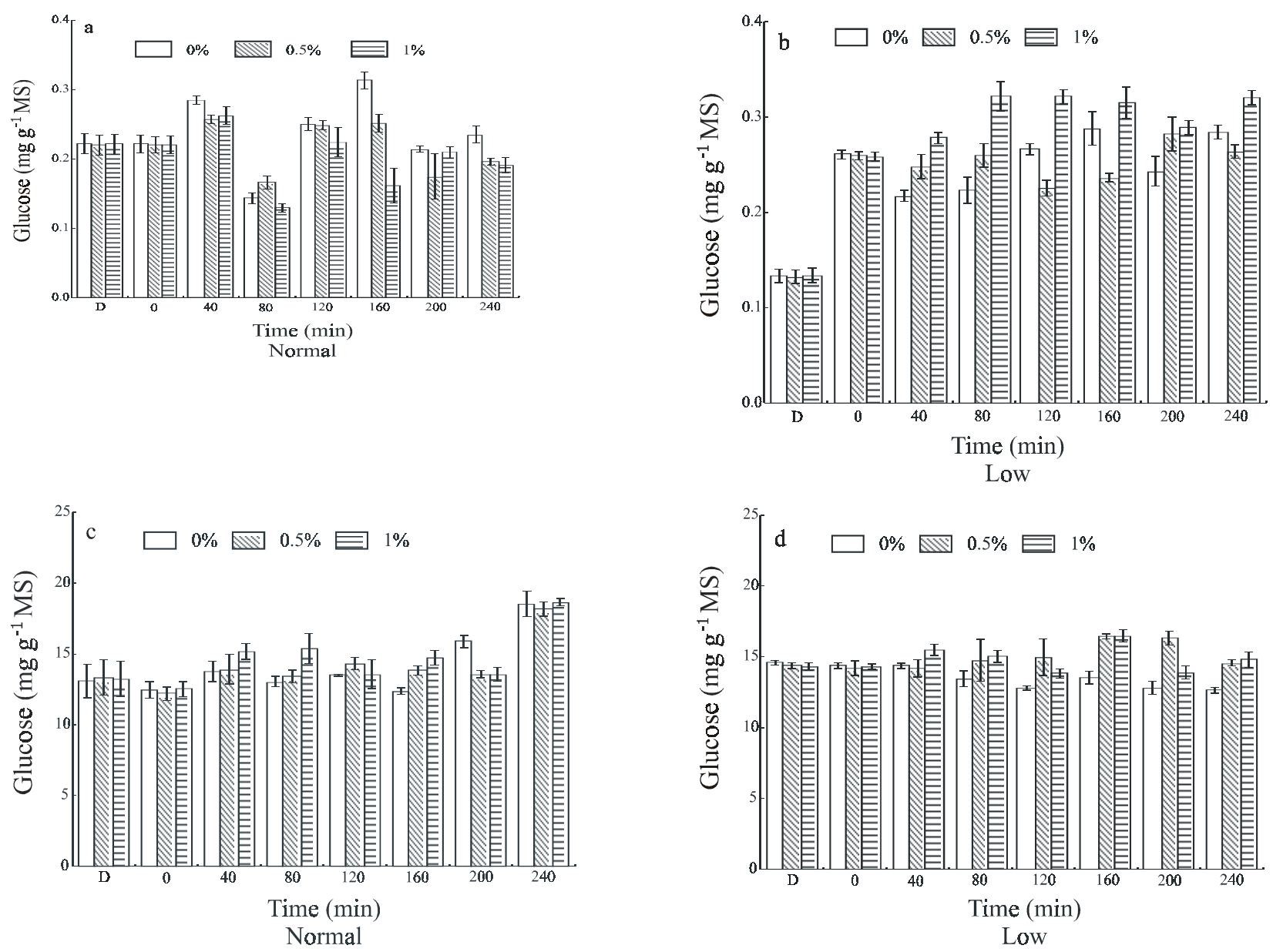

Figure 4 - Activity of vacuole acid invertase (a and b) and sucrose synthase (SUSY) (c and d) in coffee seedling leaves under two endogenous carbohydrate concentrations, normal and low, after application of sucrose at concentrations of 0.5 and $1 \%$ and water as a control, in a 40-minute assay (Bars indicate the $95 \%$ confidence interval of the mean). $D=D a r k ; 0=75$ min after start of lighted period.
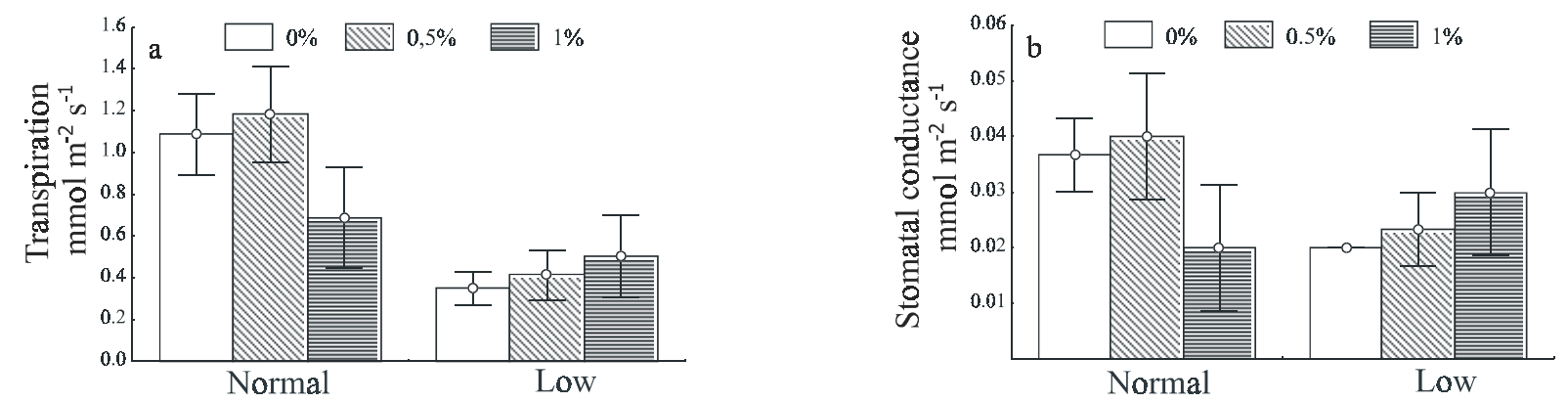

Figure 5 - Foliar transpiration (a) and stomatal conductance (b) in coffee seedling leaves under two endogenous carbohydrate concentrations, normal and low, after application of sucrose at concentrations of 0.5 and $1 \%$ and water, at time 240 minutes (Bars indicate the $95 \%$ confidence interval of the mean).

support the assertions that spraying with $1 \%$ sucrose solutions does not have an anti-transpirant action, possibly because this layer is not formed (Rena \& Fávaro, 2000).

For many crops a strong photosynthesis inhibition has been observed because of carbohydrate accumulation (Azcón-Bieto, 1986; Foyer, 1988). However, results herein obtained show that the increase in TSS experienced by depauperate plants, when sprayed with sucrose at 0.5 and 1\% (Figure 2), stimulated photosynthesis as compared to the control (Figure 6). Sucrose degradation enzymes (invertases) were immediately activated when these treatments were applied (Figures 3 and 4), not allowing carbohydrates to accumulate to a great enough extent to cause backward inhibition. On the other hand, in normal seedlings this photosynthesis stimulation was not observed (Figure 6). 


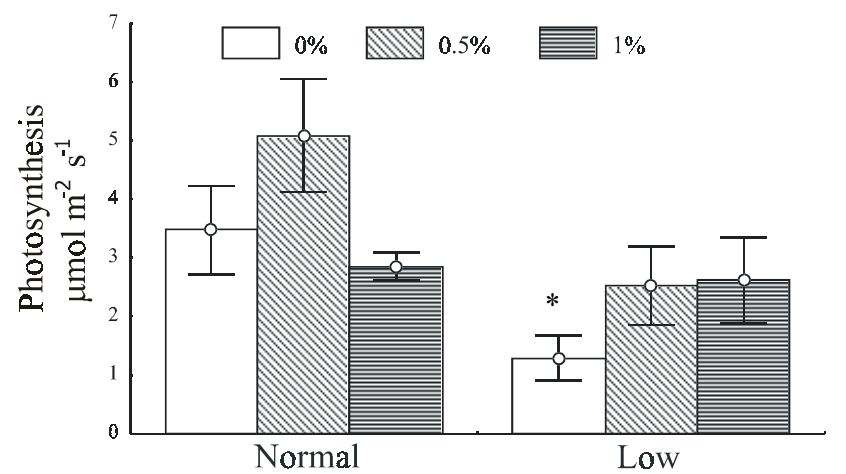

Figure 6 - Photosynthesis rate in coffee seedling leaves under two endogenous carbohydrate concentrations, normal and low, after application of sucrose at concentrations of 0.5 and $1 \%$ and water as a control, at 240 minutes (bars indicate the $95 \%$ confidence interval of the mean). *Difference $(P<0.05)$ between sugar application and water.

In plants of normal carbohydrate concentration, no increases in the concentration of endogenous sugars was observed when they were sprayed with sucrose or differences in enzyme activity (Figures 2, 3 and 4). In this case, possibly because the plants did not utilize this exogenous sugar in their tissues, the photosynthetic activity was attenuated, while in depauperate plants this increase was observed (Figure 6).

\section{REFERENCES}

AZCÓN-BIETO, J. Inhibition of photosynthesis by carbohydrates in wheat leaves. Plant Physiology, v.73, p.681-686, 1986.

CHOUREY, P.S. Genetic control of sucrose synthetase in maize endosperm. Molecular Genetis and Genetics, v.134, p.372-376, 1981.

DÉJARDIN, A.; ROCHAT, C.; MAUGENEST, S.; BOUTIN, J.P. Purification, characterization and physiological role of sucrose syntase in the pea seed coat (Pisum sativum L.). Planta, v.201, p.128-127, 1997.

FOYER, H.C. Feedback inhibition of photosynthesis through source-sink regulation in leaves. Plant Physiology and Biochemistry, v.26, p.483492, 1988.

GARCIA, A.W.R.; JAPIASSÚ, L.B.; FROTA, G.B. Avaliação da absorção de macro e micronutrientes, aminoácidos e açúcar na presença e ausência de surfactantes. In: CONGRESSO BRASILEIRO DE PESQUISAS CAFEEIRAS, 25., Franca, 1999. Anais. Brasília: MAA-PROCAFÉ, 1999. p.325-328.
GAYLER, K.; GLASZIOU, K. Physiological function of acid and neutral invertases in growth and sugar storage in sugarcane. Plant Physiology, v.27, p.25-31, 1972.

GUIMARÃES, P.T.G.; ANDRADE NETO, A. de; BELLINI JUNIOR, O.; ADÃO, W.A.; DA SILVA, E.M. A produção de mudas de cafeeiros em tubetes. Informe Agropecuário, v.19, p.98-109, 1998.

HO, L.C. Metabolism and compartmentation of imported sugar in sink organs in regulation to sink strength. Annual Review Plant Physiology, v.39, p.355-378, 1988 .

ISLA, M.I.; LEAL, D.P.; VATTUONE, M.A.; SAMPIETRO, A.R. Cellular localization of the invertase, proteinaceous inhibitor and lectin fron potato tubers. Phytochemistry, v.31, p.1115-1118, 1992.

KRUGER, N.J. Carbohydrate synthesis and degradation. In: DENNIS, D.T.; TURPIN, D.M. Plant physiology, biochemistry and molecular biology. Harlow: Longman Scientific \& Technical, 1990. p.56-76.

LIMA, D.M.; CUNHA, R.L.; SILVA, B.; MONTEIRO, J.V.; MORII, A.S.; CARVALHO, J.G. de; GUIMARÃES, R.J. Efeito de adubações foliares em pré e pós-florada na cultura do cafeeiro. In: CONGRESSO BRASILEIRO DE PESQUISAS CAFEEIRAS, 24., Poços de Caldas, 1998. Anais. Brasília: MAA-PROCAFÉ, 1998. p.193-194.

LOWELL, C.A.; TOMLINSON, P.T.; KOCH, K.E. Sucrose-metabolizing enzymes in transport tissues and adjacent sink structures in developing citrus fruit. Plant Physiology, v.90, p.1394-1402, 1989.

MANGINI, D.; PAULA, M.B. de; CARVALHO, J.G.; DIAS, F.P.; GUIMARÃES, R.J. Efeito da aplicação de boro e zinco na presença de sacarose, uréia e cloreto de potássio via foliar na nutrição mineral de produção do cafeeiro (Coffea arabica L.). In: CONGRESSO BRASILEIRO DE PESQUISAS CAFEEIRAS, 24., Poços de Caldas, 1998. Anais. Brasília: MAA-PROCAFÉ, 1998. p.198-200.

RENA, A.B.; FÁVARO, J.R.A. Nutrição do cafeeiro via folha. CaféProdutividade, Qualidade e Sustentabilidade, v.1, p.149-208, 2000.

REES, T. Sucrose metabolism. In: LEWIS, D.H. Storage carbohydrates in vascular plants. Cambridge: Cambridge University Press, 1984. p.5373.

SANTINATO, R.; FERNANDES, A.L.T.; PEREIRA, E.M. Efeito do adubo foliar nutrins na produção do cafeeiro em solo de cerrado. In: CONGRESSO BRASILEIRO DE PESQUISAS CAFEEIRAS, 24., Franca, 1998. Anais. Brasília: MAA-PROCAFÉ, 1998. p.63-64.

SEGURA-MONGE, A. Efeito da pulverização com uréia, cloreto de potássio e sacarose sobre a transpiração, potencial hídrico e nitrogênio, potássio e açúcares nas folhas de Coffea arabica $\mathrm{L}$. submetidas a défice de água. Viçosa: UFV, 1989. 38p. (Dissertação - M.S.)

WINTER, H.; HUBER, S.C. Regulation of sucrose metabolism in higher Plants: Localization and regulation of activity of key enzymes. Critical Reviews in Plant Sciences, v.19, p.31-67, 2000.

YEMM, E.W.; WILLIS, A.J. The estimation of carbohydrates in plants extracts by anthone. The Biochemical Journal, v.90, p.508-514, 1954.

$\overline{\text { Received March 06, }} 2002$ 